\title{
New Records of Two Non-native Clam Species (Bivalvia: Cardiidae) from the Coastal Waters of Bangladesh
}

\author{
Md. Royhanur Islam ${ }^{1}$, Sadman Sakin Nirob ${ }^{2}$, Md. Habibur Rahman Molla ${ }^{3}$, \\ Kauser Rahman', Md. Mozammal Haque ${ }^{3}$, M. Aminur Rahman ${ }^{4^{*}}$, \\ Saleha Khan ${ }^{5}$ and M. Zahangir Alom ${ }^{6}$ \\ ${ }^{1}$ International MS in Marine Biological Resources, Ghent University, Gent 9000, Belgium. \\ ${ }^{2}$ Faculty of Marine Sciences and Fisheries, University of Chittagong, Bangladesh. \\ ${ }^{3}$ World Fish Bangladesh and South Asia Office, House \#22/B, Road \# 7, Block \#F, Banani, Dhaka, \\ Bangladesh. \\ ${ }^{4}$ Department of Fisheries and Marine Bioscience, Jashore University of Science and Technology, \\ Jashore-7408, Bangladesh. \\ ${ }^{5}$ Department of Fisheries Management, Bangladesh Agricultural University, Mymensingh-2202, \\ Bangladesh. \\ ${ }^{6}$ Department of Fisheries, Matshya Bhaban, Dhaka-1000, Bangladesh.
}

\begin{abstract}
Authors' contributions
This work was carried out in collaboration among the authors. Authors MRI, SSN and MHRM designed the study, performed the statistical analysis, wrote the protocol and prepared the first draft of the manuscript. Authors KR and MMH managed the analyses of the study. Authors MAR, SK and MZA managed the literature searches as well as agreed on the final appearance of the manuscript after scholastic editing. All authors read and approved the final manuscript.

Article Information

DOI: $10.9734 / A R R B / 2019 / v 33 i 630137$ Editor(s):

(1) Prof. Tunira Bhadauria, Department of Zoology, Kanpur University, U.P., India. Reviewers:

(1) Fred A. Otchere, Central University, Ghana (2) Lucas Rezende Penido Paschoal, Universidade Estadual de Minas Gerais, Brazil. (3) Tatsuya Yurimoto, Japan. Complete Peer Review History: http://www.sdiarticle4.com/review-history/52578
\end{abstract}

Original Research Article

Received 22 September 2019

Accepted 24 November 2019

Published 03 December 2019

\section{ABSTRACT}

Benthic suspension feeders, such as many marine bivalve molluscs, influence the nutrient and organic cycles of benthic and pelagic systems through their ability to filter a wide size range of particles and deposit organic matters that sink to the bottom. They also play important roles in

*Corresponding author: E-mail: aminur1963@gmail.com, amin2019@just.edu.bd, aminur2017@pknu.ac.kr; 
coastal and marine ecosystems by filtering the water and serving as habitat and prey for a variety of sea life. Due to the increasing trends of environmental contaminations in recent years, many bivalves have been using as a potential biomarker for assessing the worse environment. Moreover, the shell of a bivalve is comprised of calcium carbonate, which may support thousands of calciferous organisms into the water body. Mostly, bivalves inhabit the tropics, as well as temperate and boreal waters, and they can survive and even flourish in extreme environmental conditions like Bangladesh. Nowadays, many bivalve molluscs have been identified as a superior source of bioactive compounds and are using for pharmaceutical and nutraceutical purposes as well as other applications. However, until now, few systematic studies on marine bivalve molluscs have been conducted through which a total of 437 marine and brackish water species were identified and recorded in Bangladesh. But still, our knowledge of taxonomy and systematic on marine molluscs are primitive in the context of the country. Here we report two new species of bivalve molluscs, Parvicardium exiguum and Trachycardium procerum belonging to the family Cardiidae, from the Kutubdia Island of Bangladesh. The study added these two bivalve species, which has not been recorded from the coastal zone of Kutubdia Island during the previous studies. To sum up, studies and survey on taxonomy and systematics in marine bivalves will provide new dimensions for further research about these important marine invertebrates.

Keywords: Molluscs; non-native species; new records; Kutubdia Island.

\section{INTRODUCTION}

Bivalve molluscs (oysters, scallops, clams and mussels) form a significant part of the world's fisheries production that show a diverse array of life history characteristics and perform important ecological functions [1]. Bivalves not only have epifaunal characteristics but also have infaunal lifestyles. Infaunal bivalves attached to the benthic substrate have a close relation to increasing the fertility of the barren environment. On the other hand, epifaunal bivalves use byssal threads to attach themselves to a hard surface or one another that almost assist to clean water. Bivalves are largely filter feeders, although some species, especially infaunal organisms, feed on detritus (i.e. deposit or pedal feeding). Most taxa are largely sedentary as adults, with movement documented for foraging, reproduction, and predator escape. Juvenile stages of some fauna are more likely to show mobility that is critical for dispersal [2]. Finally, bivalve assemblages can occur in high densities with ecological impacts at large spatial scales. Moreover, bivalves tolerate and accumulate contaminations and, because they are sessile and widely distributed, can be used for monitoring water turbidity and removal of contaminants [3]. The dense mussel aggregations can act as nutrients transformation hot spot in many pelagic areas, supporting the rest of the food web and altering nutrient cycling. As mussels feed, they remove phytoplankton and bacterioplankton and also detrital organic matter from the water column, metabolize the labile fractions, excrete dissolved nutrients back to the water, and deposit organic nutrients to the sediment as faeces and pseudo faeces.
Collectively, the benefits that humans derive from healthy ecosystems are considered ecosystem services. Currently, human cultures derive benefits from bivalves via direct as well as indirect use. Direct benefits include food production and commercial products such as road building material, concrete production, fertilizer, and cultured pearls. Indirect benefits of healthy bivalve communities include shoreline stabilization and nutrient mitigation [1].

Fisheries and aquaculture production of bivalves is a billion-dollar global industry. Although estuarine bivalves make up the vast majority of bivalves consumed by humans, freshwater mussels and clams (Corbicula sp.) are an important food resource in Southeast Asia [4]. In addition to food values, nowadays, many bivalve species have been found to produce several important bioactive peptides, proteins and metabolites. Among them, the numerous families of antimicrobial peptides identified in the mussels likely contribute to vigour and could assist with the identification of molecular scaffolds for innovative pharmaceuticals, nutraceuticals and constructs suitable products for other applications [5]. It has been estimated that global harvest (capture fisheries and aquaculture) of marine bivalves in 2015 was more than 16 million metric ton comprising of oysters (24\%), mussels $(18 \%)$, scallops $(25 \%)$, and clams (33\%) [6]. Estuaries around the world are in a state of decline following decades or more of overfishing, pollution, and climate change [7], and commercial bivalve capture has decreased. Future bivalve aquaculture is threatened by ocean acidification from climate change, which 
affects carbonate mineral saturation and thus impacts shell formation [1].

The southeastern coastal region, more specifically referred to as coastal islands of Kutubdia, Maheskhali and Sonadia of Bangladesh, supports diverse molluscs assemblage consisting sandy, sandy-muddy and muddy beaches, mangroves, seagrass beds, dunes and considerable profundity of the Bay of Bengal. These islands have been tended to more attention by researchers, specializing in a wide range of disciplines. In recent years, the molluscs of these islands have received clod application of the mind than other invertebrates. In these regions, it was Commans [8] who first reported some species of molluscs from the St. Martin Islands, and a subsequent study [9] described 33 species under three different classes from the same area. Later Ahmed [10] provided an extended list and taxonomic description of marine and brackish water molluscan fauna in Bangladesh, composed of 301 species belonging to 151 genera, 79 families and 16 orders in 4 classes. After that Siddique et al. [11] compiled so far 20 lands, 22 freshwater and 437 marine and brackish water molluscs species belonging to 210 genera, 105 families and 23 orders under 4 classes from Bangladesh, and are included in the volume of the Encyclopedia. But still, our knowledge of taxonomy and systematics of marine molluscs are basic in the context of Bangladesh. This is not only due to short-skilled people and tools to study them, but also owing to the problems in morphological analysis and identification of molluscs as a result of their complex larval stages, phenotypic plasticity and substantial cryptic species diversity. While deciding to prepare a monograph of the marine gastropods and bivalves of the Kutubdia, Maheskhali and Sonadia Island to comprehend the status and diversity of molluscs assemblage, we verified two species belonging to the family Cardiidae that are new not only in this region but also in Bangladesh. After examining the associated specimens at the laboratory of Institute of Marine Sciences and Fisheries, University of Chittagong, Bangladesh, we ascertained the species Parvicardium exiguum (Gmelin, 1791) [12] and Trachycardium procerum Mörch, 1853 [13] as new records to Bangladesh. The habitat of proposed specimens in the intertidal area was also discussed.

\section{MATERIALS AND METHODS}

Mollusc samples were collected from the intertidal and subtidal habitats at locations across the southeastern coastal region namely Kutubdia Island of Bangladesh, from January 2013 to December 2013. The exact location of the study area is shown in Fig. 1. One sample from each specimen was kept in the laboratory catalogue of Institute of Marine Sciences and Fisheries, University of Chittagong (Code Numbers: MSC/IMSF C0248 and MSC/IMSF C0181). Systematic information was based on the descriptions of Van Aartsen and Goud [14]; Coan and Valentich-Scott [15] and WoRMS (World Register of Marine Species database). An updated checklist of species under the family Cardiidae from the coastal zone of Bangladesh was compiled based on the published reports of Ahmed [10] and Siddique et al. [11].

\subsection{Material Examined}

The sample (Parvicardium sp.) collection area was situated at Kutubdia Island i.e. South Kutubdia Island-Ali Akbar Deil to be more exact. Measurement was conducted with a digital slide caliper (Model: TOL-000204). The sample had been collected by the hand picking method two times in a month during the lowest low tide period. For the matured individual, the entire collected specimen from the sampling site was similar size and the SL was $24 \mathrm{~cm}$ on an average.

The shell was collected from the surface of the intertidal sand muddy zone and the shell size (dyke to $25 \mathrm{~m}$ ) of the matured living individual was measured to be $10-24 \mathrm{~mm}$. According to WoRMS, the shell length was found to be varied from 10 to $20 \mathrm{~mm}$. Similar shell length of the species up to $20 \mathrm{~mm}$ was also documented [14]. The sample (Trachycardium sp.) collection place was in Kutubdia Island at the same place more exactly referred to as the South Kutubdia Island-Ali Akbar Deil. The shell was collected from the intertidal mangrove planted (sand-muddy) zone and shell length of matured living individuals was up to $105 \mathrm{~mm}$. The shell length varies from 50.0 to $122.5 \mathrm{~mm}$ (WoRMS), and Coan and Valentich-Scott [15] documented the shell length of $102 \mathrm{~mm}$ and height of 117 $\mathrm{mm}$.

\section{RESULTS AND DISCUSSION}

The recent investigation informs about the first record of two marine bivalves, Parvicardium exiguum [12] and Trachycardium procerum [13] belonging to the family Cardiidae from the Coastal Islands of Bangladesh. 


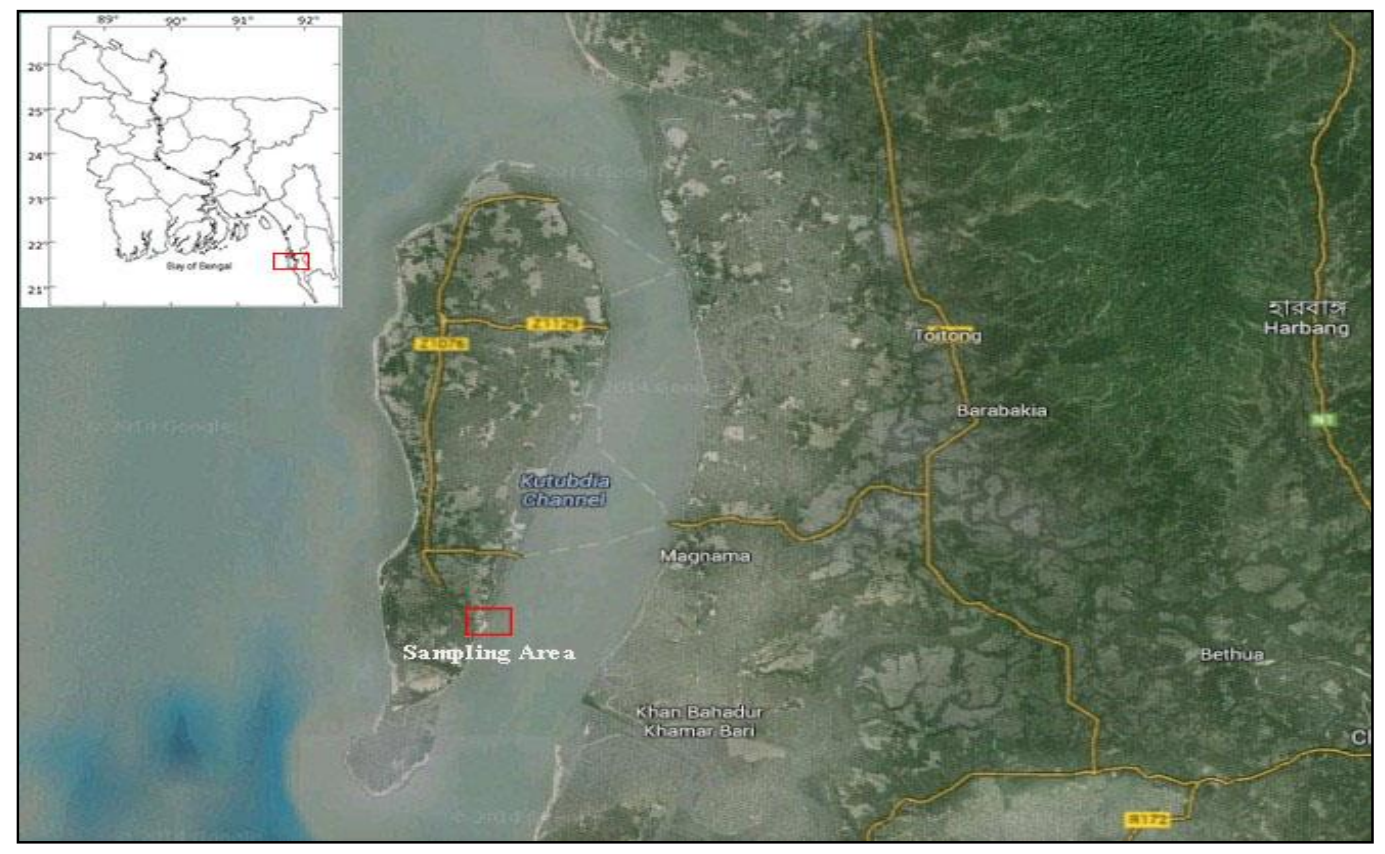

Fig. 1. Map of the study area at Kutubdia Island, Bangladesh (taken from Google Maps ${ }^{\circledR}$ )

\subsection{Systematics of Parvicardium sp.}

$\begin{array}{ll}\text { Class } & \text { : BIVALVIA } \\ \text { Sub-class } & \text { :HETERODONTA } \\ \text { Order } & \text { :VENEROIDA } \\ \text { Super family } & \text { : CARDIOIDEA } \\ \text { Family } & \text { : CARDIIDAE } \\ \text { Genus } & \text { : Parvicardium Monterosato, 1884 } \\ & \text { Parvicardium exiguum (Gmelin, } \\ & \text { 1791) (Fig. 2) }\end{array}$

\subsubsection{Description of shell}

The thick shell (equivalve) with prominent beaks in front of the midline, anterior strong hinge line and tumid were documented. It comprised of 2022 width radial ribs, with distinguished concentric ridges; at young, short tubercle-like spines were present on all ribs and in the mature stage, these spines were seen at anterior and posterior ends when ventral margin gently curved. During the distinct development stage, two small cardinal teeth in each valve, two anterior teeth in right valve and one lateral tooth in posterior part with small upper anterior portion were monitored. Moreover, the single anterior in the left valve with lateral posterior part has been seen while more prominent anterior found at the same time. Marginal crenulations with interlocking ribs, interspaces, not extended in the interior, apparent pallial line and adductor scars, smooth oval lunule and prominent ligament on short nymph were also documented.

\subsubsection{Distribution}

The specimen was found in sand, gravel or mud; from the lower shore into the shallow sublittoral zone, often extended into the estuaries [16] and also subtidal to 5 meters for common species [17]. The species also occurred shallow burrow in the sand, muddy sand and mud from the low intertidal to shallow shelf depths, extending into estuaries. The genus of the family was observed in the shallow burrow of the sandy to muddysand flats, forming beds [11]. The species inhabited in the depth range between intertidal continental shelf to $200 \mathrm{~m}$, were found to be widely distributed in the Indo-Pacific and also occurred in the Mediterranean [14]. However, no previous record of this species from the coastal Islands of Bangladesh was evident.

Table 1. List of species of the family Cardiidae, identified from the coastal zone of Bangladesh

\begin{tabular}{lll}
\hline Family & Species & References \\
\hline Cardiidae & Trachycardium asiaticum & Ahmed [10], Siddique et al. [11] \\
& Trachycardium flavum & Ahmed [10], Siddique et al. [11] \\
& Trachycardium enode & Siddique et al. [11] \\
\hline
\end{tabular}




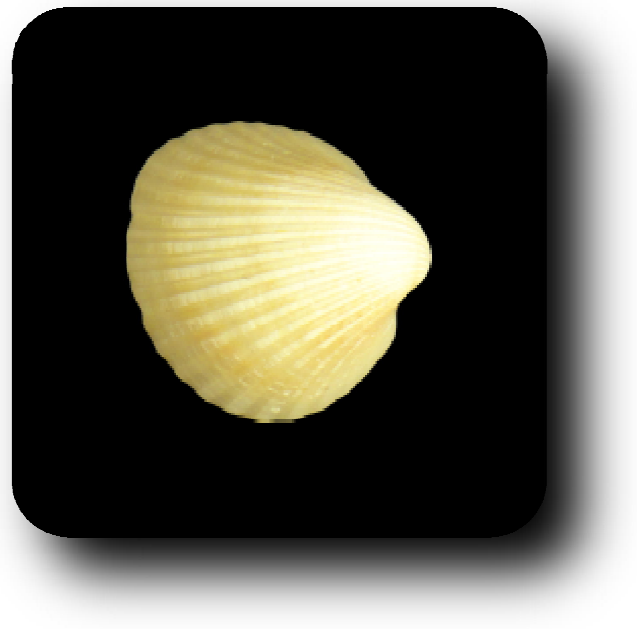

a. Dorsal view

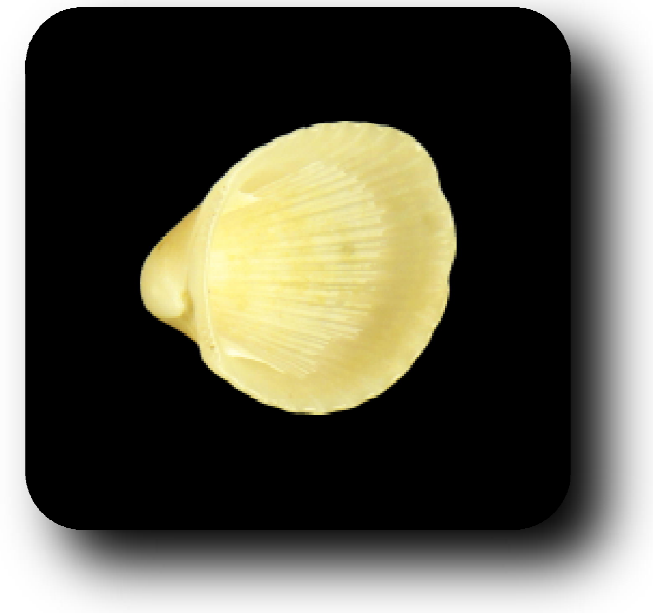

b. Ventral view

Fig. 2. Photograph of Parvicardium exiguum (Gmelin, 1791) [12]: a) Dorsal view and b) Ventral view

\subsubsection{Remark}

The new record for Parvicardium exiguum was discovered from Kutubdia Island, Bangladesh. The species are mostly available and found only in the sandy-muddy zone of the intertidal area. It prefers an aerial exposure on $0-5 \%$ and is found in rough sand and sand gravel spun with a byssus thread [18]. The genus of the family was found in intertidal and shallow sublittoral waters to a depth of about $15 \mathrm{~m}$ [11]. It was also found on the rock under algae with byssal attachment [19]. The species was also reported from the widely distributed coastal area of Norway to the Mediterranean and Black Sea [14]; Western Europe subtidal to $5 \mathrm{~m}$ of depth was common [17].

\subsection{Systematics of Trachycardium sp.}

$\begin{array}{ll}\text { Class } & \text { : BIVALVIA } \\ \text { Sub-class } & \text { : HETERODONTA } \\ \text { Order } & \text { : VENEROIDA } \\ \text { Super family } & \text { : CARDIOIDEA } \\ \text { Family } & \text { : CARDIIDAE } \\ \text { Genus } & \text { : Trachycardium Mörch, 1853 } \\ & \text { Trachycardium procerum } \\ & \text { Sowerby I, 1833) (Fig. 3) }\end{array}$

\subsubsection{Description of shell}

The documented shell (ovate) was thick with nearly rounded posterior periostracum. Shell height was larger than its length. Radial ribs were covered by weak crossbars on top with 22-23 radial ribs. The inner margin was crenulated with more flattened radial ribs at the anterior and posterior ends. External colour of it had tan to medium brown with flecks.

\subsubsection{Distribution}

The species was originated from the marine environment, more specifically on the Mexican part of the North Pacific Ocean and Chilean Exclusive Economic Zone in the South Pacific Ocean (WoRMS). It has been found mostly at the Pacific coast of Baja California, and most specimens occurred from the Golfo de California [15] and also recognized from the northern end of the Panamic Province [20]. Finally, Abbott and Dance [17] collected this species in shallow waters from the SW Mexico to Chile. No previous record of this species from the coastal Islands of Bangladesh was reported. The species commonly inhabited shallow burrows in sandy to muddy-sand flats, forming beds. It usually has separate sexes and the development proceeded with free-swimming larval stage and occurred inside burrows in the intertidal and shallow sublittoral waters to a depth of about $15 \mathrm{~m}$ B. $[10,11]$.

\subsubsection{Remark}

The new record was identified from Kutubdia Island, Bangladesh. This species is common and mostly found in mangrove planted intertidal (sandy-muddy) area. Siddique et al. [11] had noticed that the habitats of the species from the 


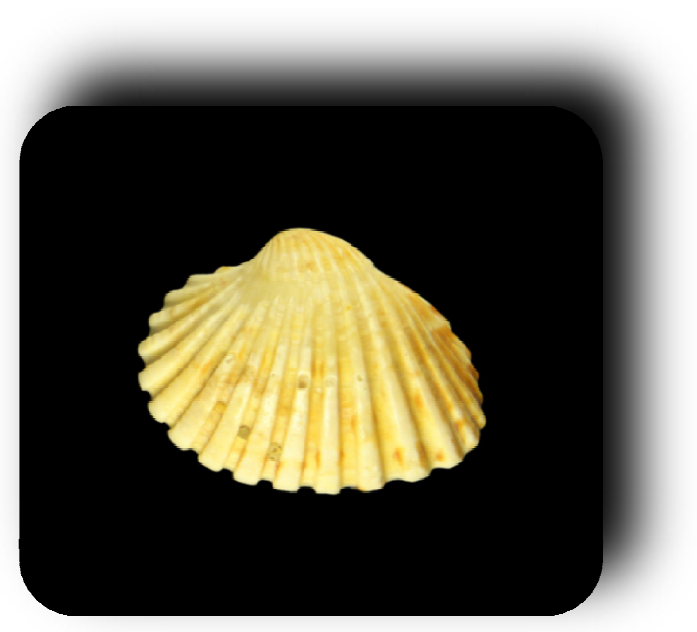

a. Dorsal view

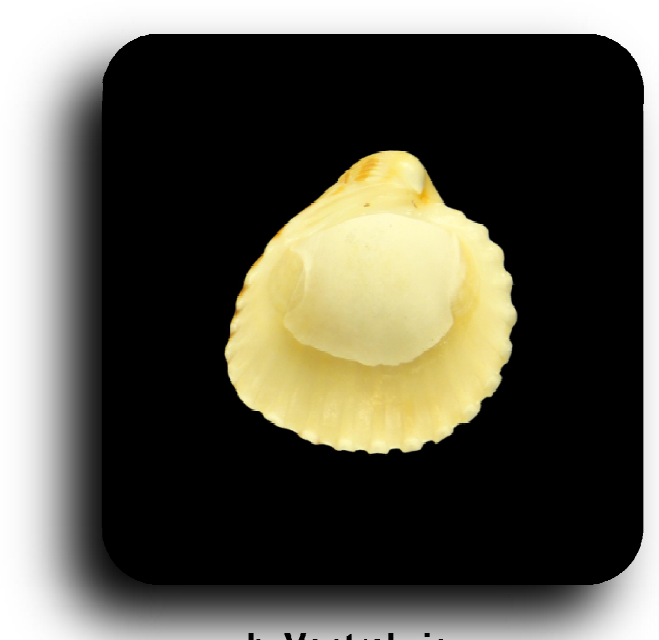

b. Ventral view

Fig. 3. Photograph of Trachycardium procerum (G. B. Sowerby I, 1833) [13]: a) Dorsal view and b) Ventral view

same genus (Table 1) were between St. Martin Island and Sonadia Island, widespread in the Indo Pacific from East Africa to the Philippines, Taiwan and Indonesia, including India, Myanmar and Sri Lanka [11]. The species was also reported from the coastal area of North and South Pacific Ocean (WoRMS), SW Mexico to Chile [17], and Pacific coast of California [15]. The survey had been conducted for collecting molluscs from the coastal zone of Bangladesh by the scientific community as well as an individual researcher since 1940. The specimens are now under the preservation of laboratory and many of them are documented in wellknown scientific articles. A total of 142 marines and 6 freshwater bivalves were monitored [11], in which 125 species belonging to 19 families were documented in Kutubdia, Maheskhali and Sonadisa [21]. Among them, 6 species were from the family Cardiidae, which has been included in the recent record. We collected a great number of specimens during our field studies but were able to work on a limited number of species for the time being. Therefore, further studies are required to make a complete precision on the species and speciation processes of the bivalves around the region.

\section{CONCLUSION}

To sum up, studies and survey on taxonomy and systematic on marine bivalves will provide new dimensions for further research about mollusks. Moreover, the study provides a new issue for further studies leading to uses, maintenance, management as well as protection/conservation of our mollusks and their habitats in Bangladesh [22].

\section{ACKNOWLEDGEMENT}

Authors would like to extend grateful thanks and appreciations to Professor Dr. M Shahadat Hossain, Faculty of Marine Sciences and Fisheries (FMSF), University of Chittagong, Bangladesh, for his scholastic suggestions and guidance during this research work. Authors also sincerely remember the kind-hearted peoples of the Ali Akbar Deil, Kutubdia Island as well as Joynal Abedin, Field Stuff of FMSF, University of Chittagong, Bangladesh for their untiring support during the field work.

\section{COMPETING INTERESTS}

Authors have declared that no competing interests exist.

\section{REFERENCES}

1. Vaughn CC, Hoelle TJ. Bivalves impacts in freshwater and marine ecosystems. Annual Review of Ecology, Evolution, and Systematics. 2018;49(1):183-208.

2. Molla MHR, Hasan MT, Jang WJ, Diaz CDS, Appenteng $\mathrm{P}$, Marufchoni $\mathrm{H}$, Jahan $\mathrm{B}$, Brown CL. Thyroid hormone-induced swim bladder and eye maturation are 
transduced by IGF-1 in zebrafish embryos. Aquaculture Research. 2019;00:1-9.

3. Gifford S, Dunstan RH, Connor W, Koller CE, MacFarlane GR. Aquatic zoo remediation: Deploying animals to remediate contaminated aquatic environments. Trends in Biotechnology 2007;25: 60-65.

4. Zieritz A, Bogan AE, Froufe E, Klishko O, Kondo T. Diversity, biogeography and conservation of freshwater mussels (Bivalvia: Unionida) in east and southeast Asia. Hydrobiologia. 2018;810:29-44.

5. Venier $P$, Gerdol M, Domeneghetti $S$, Sharma N, Pallavicini A, Umberto R. Biotechnologies from marine bivalves. In: Smaal AC, Ferreira JG, Grant J, Petersen JK, Strand $\varnothing$, Editors. Goods and Services of Marine Bivalves, Springer Open, Library of Congress Control Number: 2018951896. 2019;95-112.

6. FAO (Food and Agricultural Organization). FAO Yearbook of Fishery and Aquaculture Statistics 2015. Rome: Food and Agricultural Organization, UN; 2017.

7. Rick TC, Reeder-Myers LA, Hofman CA, Breitburg D, Lockwood R. Millennial-scale sustainability of the Chesapeake Bay Native American oyster fishery. Proceedings of the National Academy of Sciences of the United States of America. 2016;113:6568-73.

8. Coomans HE. The marine Mollusca of St. Martin. Lesser Antilles, collected by Krebs HJ. Studies on the Fauna of Curafao. 1963;16:59-87.

9. Ali S, Aziz KMS. A systematic account of molluscan fauna of the Saint Martin's Island. Bangladesh Journal of Zoology. 1976;4(2):23-33.

10. Ahmed ATA. Studies on the identity and abundance of molluscan fauna of the Bay of Bengal. Final report, Bangladesh Agricultural Research Council (BARC), Dhaka. 1990;118.

11. Siddique $\mathrm{KU}$, Islam $\mathrm{MA}$, Kabir $\mathrm{SMH}$, Ahmed M, Ahmed ATA, Rahman AKA, Haque EU, Ahmed ZU, Begum ZNT, Hasan MA, Khondker M, Rahman MM, (Eds). Encyclopedia of Flora and Fauna of Bangladesh. Molluscs. Asiatic society of Bangladesh. 2007;17:415.

12. ter Poorten J, Gofas S. Parvicardium exiguum (Gmelin, 1791). Accessed through: World Register of Marine Species; 2015.
Available:http://www.marinespecies.org/ap hia. php? $p=$ taxdetails $\&$ id $=139008$

(Accessed on 2015-03-27)

13. ter Poorten J, Bouchet P. Trachycardium procerum (G. B. Sowerby I, 1833). Accessed through: World Register of Marine Species; 2015.

Available:http://www.marinespecies.org/ap hia. php? $p=$ taxdetails\&id $=519474$ (Accessed on 2015-03-27)

14. Van Aartsen JJ, Goud J. European marine mollusca: Notes on less well-known species. XV. Notes on Lusitanian species of Parvicardium Monterosato, 1884, and Afrocardium richardi (Audouin, 1826) (Bivalvia: Heterodonta: Cardiidae). Basteria. 2000;64:171-186.

15. Coan EV, Valentich-Scott P. Bivalve seashells of tropical West America. Marine Bivalve Mollusks from Baja California to Northern Peru. 2 vols. Santa Barbara: Santa Barbara Museum of Natural History. 2012;1258.

16. de Kluijver MJ, Ingalsuo SS, de Bruyne $\mathrm{RH}$. Macro benthos of the North Sea [CDROM]: 1. Keys to Mollusca and Brachiopoda. World Biodiversity Database CD-ROM Series, Expert center for Taxonomic Identification (ETI): Amsterdam. ISBN 3-540-14706-3.1 cdrom; 2000.

17. Abbott RT, Dance SP. Compendium of seashells. Odyssey Publishing, USA. 2000;424.

18. Jelnes JE, Hopner Petersen G, Russell PJC. Isoenzyme taxonomy applied on four species of Cardium from Danish and British waters with a short description of the distribution of the species (Bivalvia). Ophelia. 1971;9:15-20.

19. Petersen GH, Russell PJC. Cardium hauniense compared with $C$. exigum and C. glaucum. Proceedings of the Malacological Society of London. 1971;39: 409-420.

20. Keen AM. Sea shell of Tropical West America; Marine Mollusks from Baja California to Peru. Stanford University press, Stanford. 1971;1064.

21. Hossain MS, Sharifuzzaman SM, Chowdhury SR, Chowdhury SHN, Sarker $S$, Islam MR, Talukder A. Sea shells of Bangladesh. Marine Gastropod and Bivalve, Mollusc biodiversity. Center of Coast, climate and community, University of Chittagong. 2014;1-56. 
22. Molla MHR, Islam MS, Rahman MA, Lee SG, Jahan B, Iqbal J, Mamtaz S. An assessment of geo-morphology and hydrobiological factors of major wetlands of Bangladesh. Water Science and Technology. 2018;78:578-587.

Available:https://doi.org/10.2166/wst.2018. 328

(c) 2019 Islam et al.; This is an Open Access article distributed under the terms of the Creative Commons Attribution License (http://creativecommons.org/licenses/by/4.0), which permits unrestricted use, distribution, and reproduction in any medium, provided the original work is properly cited.

Peer-review history:

The peer review history for this paper can be accessed here:

http://www.sdiarticle4.com/review-history/52578 